
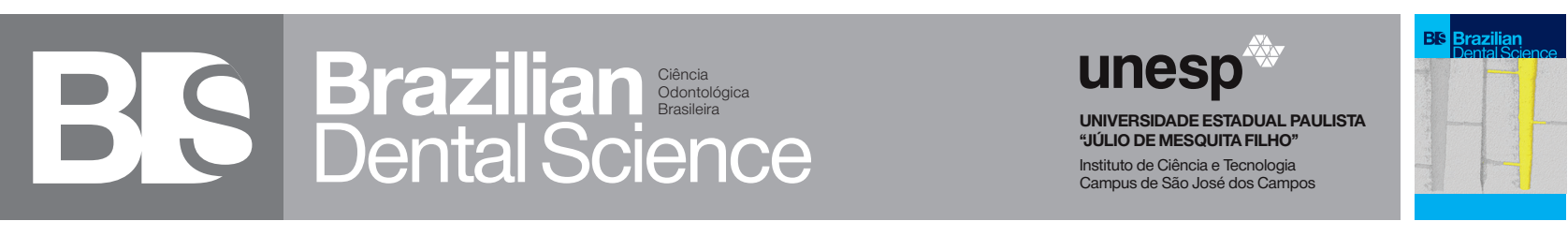

\title{
Comparison between open and closed-tray impression techniques on the implant transfer accuracy
}

\author{
Comparação das técnicas de moldagem com moldeira aberta e fechada na precisão da transferência de implantes \\ Karen Petená MORETTI ${ }^{1}$, Rafael Antônio DE CASTRO ${ }^{1}$, Patrícia Aparecida ANA ${ }^{2}$, Renata Pilli JÓIAS ${ }^{1}$, Renato Morales JÓIAS ${ }^{3}$ \\ 1 - Methodist University of São Paulo - School of Dentistry - Department of Orthodontics - Sao Paulo SP - Brazil. \\ 2 - Federal University of ABC - Center of Engineering, Modeling, and Apllied Social Sciences - Sao Bernardo do Campo - SP - Brazil. \\ 3 - Methodist University of São Paulo - School of Dentistry - Department of Prosthodontics - SP - Brazil.
}

\section{ABSTRACT}

Objective: This in vitro study aimed to determine and compare the dimensional accuracy of open and closed-tray impression techniques for implantsupported prosthesis. Material and Methods: On a edentulous master model, four external hexagonal implants were parallelly installed and associated with four multi unit coping transfers and four multi unit rotational caps. A master superstructure was constructed and splinted all implants (control group). Five customized trays were constructed to perform ten open $(n=5)$ and closed-tray $(n=5)$ impressions. The obtained models were submitted to the dimensional analysis on three points in the center of the labial face of each implant (A, B, C, and D) with the aid of Stereoscopic Magnifying Glass with x60 magnification. The vertical misfit between the metallic structure and the implant analogues was measured on each point. The obtained results were submitted to Dixon's normality test and KruskalWallis test for independent samples $\mathrm{p}<0.05$ ) with the aid of Bioestat 5.0 software. Results: The means and standard deviation were: open tray technique - $24.6474 \pm 14.8883 \mu \mathrm{m}$; closed-tray technique $26.2257 \pm 9.7421 \mu \mathrm{m}$; and control group 22.445 $\pm 7.7106 \mu \mathrm{m}$. Conclusion: The accuracy of open and closed-tray impression techniques showed no statistically significant differences and both techniques were effective for implant transfer.

\section{KEYWORDS}

Dental implants; Dimensional measurement accuracy; Dental prosthesis, implant-supported; Dental impression technique.

\section{RESUMO}

Objetivos: O presente estudo in vitro objetiva determinar e comparar a precisão dimensional das técnicas de transferência de implantes direta e indireta para próteses implantossuportadas. Material e Métodos: a partir de um modelo mestre mandibular desdentado, foram instalados paralelamente quatro implantes hexágonos externos associados a quatro componentes multi unit e quatro capas multi unit rotacionais. Confeccionou-se uma infraestrutura mestre metálica unindo todos os elementos, considerando o conjunto como grupo controle (GC). Ao todo, fabricaram-se cinco moldeiras individuais para realizar 10 moldagens mediante as técnicas direta e indireta $(n=5)$, sendo os modelos obtidos submetidos à análise dimensional e estatística. Com uma lupa estereoscópica binocular com ampliação de $60 \mathrm{x}$, estabeleceram-se três pontos no centro da face vestibular de cada um dos implantes (A, B, C e D) por amostra. Em cada ponto, mensurou-se o desajuste vertical entre a estrutura metálica e os análogos. Os resultados obtidos foram submetidos ao teste de normalidade de Dixon e teste de Kruskal- Wallis para amostras independentes $(\mathrm{p}<0,05)$ com o auxílio do software Bioestat 5.0. Resultados: médias aritméticas e desvio padrão identificados no grupo moldagem direta $(24,6474 \pm 14,8883 \mu \mathrm{m})$ e moldagem indireta $(26,2257$ $\pm 9,7421 \mu \mathrm{m})$ em comparação com o modelo mestre $(22,445 \pm 7,7106 \mu \mathrm{m})$. Conclusão: Pôde-se concluir que não houve diferenças estatísticas significativas entre as técnicas na precisão da transferência de implantes, sendo ambas igualmente eficientes.

\section{PALAVRAS-CHAVE}

Implantes dentários; Precisão da medição dimensional; Prótese dentária fixada por implante; Técnica de moldagem odontológica. 


\section{INTRODUCTION}

$\mathrm{T}_{\mathrm{H}}^{\mathrm{h}}$ he appearance of Implantodontics and the use of osseointegrated implants positively contributes to the oral rehabilitation of edentulous individuals [1-6], employing plausible methodologies with constant increasing in scientific area. Recent published studies [12,4-12] claim for techniques which construct a definitive and accurate study cast that reliably copies the intraoral position of implants and/or abutments, thus promoting better conditions for adaptation, retention, and stability.

Even knowing that the absolute passive adaptation of the implant-supported prosthesis is very difficult to be clinically achieve in partial or total edentulous individuals $[5,7,10,13$ $16]$, it is possible to decrease the dimensional alterations that affect the precision by controlling the steps of: construction of the implant superstructure $[4,7,10-11,13-16]$, handling of the impression material $[1,2,13]$, and implant transfer impression technique [23,5,7,9-11,13-16]. However, in some cases, small maladjustments are acceptable and do not imply in further complications $[10,17]$.

An implant-supported prosthesis with maladapted superstructure can cause serious mechanical [1-5,7-8,14,17-22] and biological complications [2,4-5,7-8,14,17-22], such as: fracture and/or loss of threads $[1-2,4,8,17,19$ $22]$, implant fracture $[2,4,8,17,19-22]$, occlusal problems $[2,4,22]$, biofilm accumulation $[17,22]$, and even loss of osseointegration [8,19-22].

A natural tooth can move above $100 \mu \mathrm{m}$ inside the periodontal ligament and the tooth displacement is compensated by installing a fixed partial prosthesis. On the other hand, the osseointegrated implant movement is limited to $10 \mu \mathrm{m}$ in average and its lack of intrusion generates a force on the restauration, which if not relieved, cause all the complications cited above $[5-6,9,18]$. Thus, it is necessary to evaluate the factors accounting for relieving the lack of flexibility of the implants that can directly influence on the transfer impression as well as the reliability with the original control geometry $[2,9-10,23]$.
The laboratorial procedures are among such factors as: chosen implant transfer impression technique [2-5,7-10,16-19,23$25]$; choice of tray $[3,23,25]$; impression material type $[1-2,5,7,9-10,16-17,19,23-25]$; implant connection system [2,7,9-10,16-19]; connection material type [11,18-19]; deepness $[7,10,17]$, position [16-17], number [16,23], and angulation of the implants $[1,5,7,10,16$ 17,19]; length of the transfer copings [7]; plaster dimensional stability used for pouring the cast [5-7], among others.

The implant transfer impression technique largely influences on the accuracy of the working casts obtained for the construction of the implant-supported prosthesis [2-5,8$9,11,20,22,26]$ because the transfer impression technique aims to record the tridimensional implant position $[2,8]$ and to copy details as deepness, angulation, and position in relation to other implants, adjacent teeth, and antagonist arch [8].

To sum up, two impression techniques have been used to transfer the implant position in mouth to the study cast: direct (open tray) and indirect (closed tray) techniques. The direct technique (open tray) $[5,8,12,17,20,22,27,28]$, with or without splinting, requires the construction of a customized tray with a perforation on the area of the implants to make the insertion of the transfer copings easy. After the impression, the transfer copings are loosening to be removed together with the impression. The open-tray technique is specially indicated for impression of more than three implants to reduce the effects caused by angulation, to decrease the impression material deformation, and to eliminate the caution in repositioning the transfer coping in the respective space in the impression. The direct impression drawbacks are the difficult and the need of expertise to remove all the impression+transfer coping set from the mouth $[3-5,12,18,19,21]$.

In the indirect technique (closed tray) $[3,5,8,12,17-22,27,28]$, the transfer copings are fixed to the implant and splinted to the implant after the impression removal. Then, the transfer coping is loosened, screwed to the analogue, and inserted in the impression 
manually. This is a simpler and faster, but less accurate procedure that is indicated in cases with one/two implants in individuals with limited mouth opening and/or marked vomiting reflex; or in situations in which not enough space is available to access the transfer copings; or in the presence of angulated implants $[3,5,8,12,17-22,27,28]$.

This in vitro study aimed to determine and compare the dimensional accuracy of open and closed-tray implant transfer impression technique for implant-supported prosthesis. The hypotheses are: (1) the open-tray technique is more accurate than closed-tray technique; (2) the closed-tray technique is more accurate than open-tray technique; and (3) both techniques have similar accuracy in implant transfer technique.

\section{MATERIAL AND METHODS}

\subsection{Master model}

The mandibular edentulous master model was constructed with chemically-activated acrylic resin (Jet; Artigos Odontológicos Clássico Ltd, São Paulo, Brazil). Then, four 4 x $10 \mathrm{~mm}$ external hexagonal implants (Inp; Sistema de Implantes Nacional e de Próteses Comércio Ltda, São Paulo, Brasil) were parallelly fixed on master model.

\subsection{Master metallic structure}

The control group (CG) comprises the master metallic superstructure. Initially four implants were associated to four multi unit transfer copings (Inp; Sistema de Implantes Nacional e de Próteses Comércio Ltda, São Paulo, Brazil) and four multi unit rotational cobalto- chromium caps (Inp; Sistema de Implantes Nacional e de Próteses Comércio Ltda, São Paulo, Brazil). These were fixed to the master model with the aid of threads Mix (Mult Unit M $1.4 \times 3.5$ ) under torque of $20 \mathrm{Ncm}$ on each implant. The torque was calibrated with the aid of torque wrench (Kit Protético, INP, SP, Brazil) according to the manufacturer's instructions.

Two bars were constructed with $1-\mathrm{mm}$ stainless steel orthodontic wire (Remanium $\AA$ Sisprodent, Produtos Odontológicos) to splint the implants. The bars were tied together with the aid of $0.45 \mathrm{~mm}$ wire (Morelli Ortodontia) and fixed with chemically-activated acrylic resin (Dencor Lay; Artigos Odontológicos Clássico Ltd, São Paulo, Brazil) [Figure 1].

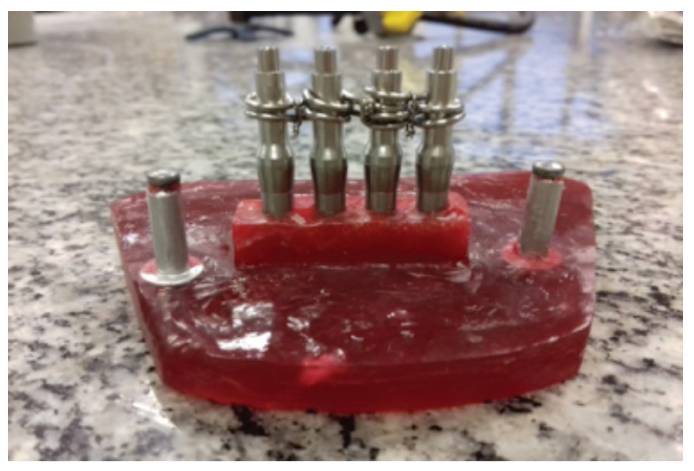

Figure 1 - Master model and master metallic structure.

\subsection{Customized trays}

On the installed implants, a 3-mm relief with condensation silicone (Optosil @; Heraeus Kulzer) was made aiming to achieve a uniform thickness of the impression material and an adequate positioning of the trays during the procedure [Figure $2 \mathrm{a}$ ].

Then, a base structure for the construction of all trays were obtained. The general dimensions (base, height, width, deepness, and relief contour) were marked with the aid of pink wax \#7 (Lysanda ( ${ }^{\circledR}$ - Produtos Odontológicos Ltd.) [Figure 2b and 2c]. Next, the base structure was filled with condensation silicone (Xantopren ${ }^{\circledR}$, Heraeus Kulzer) and catalyzer (Activator, Heraeus Kulzer) [Figure 2d].

Five $3-\mathrm{mm}$ open trays were constructed with chemically-activated acrylic resin (Jet; Artigos Odontológicos Clássico Ltd, São Paulo, Brasil). To obtain the indirect implant transfer impression technique and the closed trays, five acrylic plates were cut $(1.8 \times 3.8 \mathrm{~cm})$ and fixed on the open trays with the aid of chemically-activated acrylic resin (Jet; Artigos Odontológicos Clássico Ltd, São Paulo, Brazil) [Figure 2e]. 


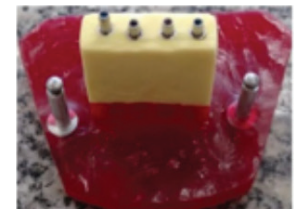

(a)

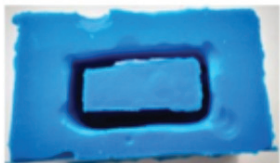

(d)

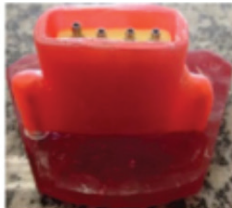

(b)

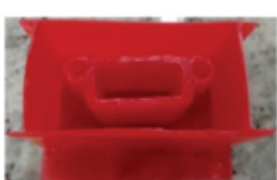

(c)

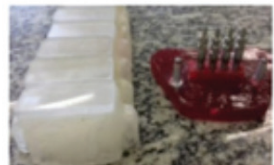

(e)
Figure 2 - a) Implant relief with Optosil (B; b) construction of the customized tray with dental wax A7; c) dental wax mold to duplicate the customized trays; d) Filling with Xantopren $®$; e) chemically-activated acrylic resin (Jet @) customized trays.

\subsection{Samples}

Five impressions with condensation silicone (Xantopren ${ }^{\circledR}$, Heraeus Kulzer) were executed for each one of the groups $(n=5)$ : Group 1- open tray technique and Group 2closed tray technique.

In Group 1, after the transfer coping installation and the application of an universal adhesive for silicone impressions (Universal Tray Adhesive, Zhermack) on the customized tray, the impression material was inserted and an impression of the master mold was taken. After the impression material setting, the opentray digital multi unit threads (Inp; Sistema de Implantes Nacional e de Próteses Comércio Ltda, São Paulo, Brasil) were loosened [Figure 3a] and the transfer copings removed together with the impression [Figure 3b]. Then the transfer copings were screwed on the respective analogues (Inp; Sistema de Implantes Nacional e de Próteses Comércio Ltda, São Paulo, Brazil) [Figure 3c].

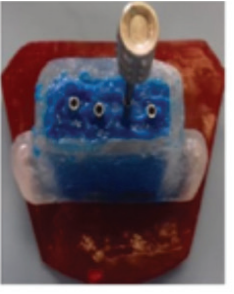

(a)

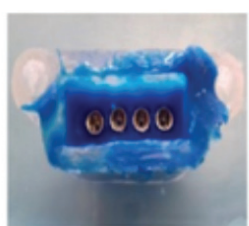

(b)

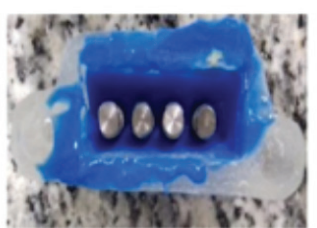

(c)
Figure 3 - Open tray technique). a) filling of the customized tray with Xantopren ${ }^{\circledR}$, impression, and loosening of the transfer copings; b) impression with Xantopren $₫$ and transfer copings; c) insertion of analogues.
In Group 2, the transfer copings were screwed with the aid of multi unit digital threads (Inp; Sistema de Implantes Nacional e de Próteses Comércio Ltda, São Paulo, Brazil) for closed trays. The labial surfaces of these threads were marked with permanent pen. Then, an universal adhesive for silicone impressions (Universal Tray Adhesive, Zhermack) was applied on the tray and the impression material was inserted and an impression of the master mold was taken. After the impression material setting [Figure 4a], the impression was removed, the transfer copings loosened, screwed to their respective analogues (Inp; Sistema de Implantes Nacional e de Próteses Comércio Ltda, São Paulo, Brazil) [Figure 4b], and inserted in the impression manually [Figure 4c].

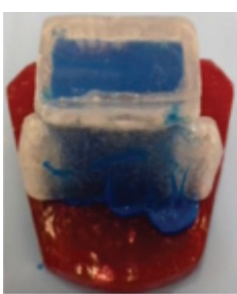

(a)

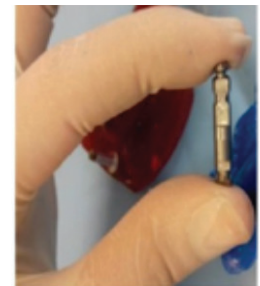

(b)

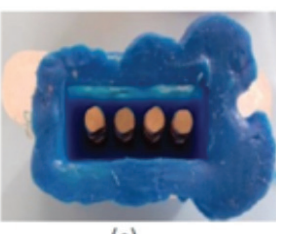

(c)
Figure 4 - Closed tray technique. a) filling of the customized tray with Xantopren $®$ and impression; b) loosening of the transfer coping and manually screwing to the analogues; c) manual insertion of the transfer copinglUanalogue set into the mold.

Finally, all impressions were immediately poured with type IV dental plaster (Durone®) and elapsed one hour, the impressions were removed and the working casts obtained [Figures 5a and 5b] to be dimensionally compared to the control group (GC).

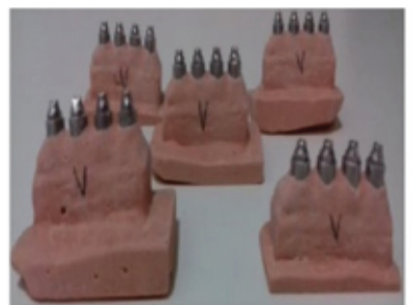

(a)

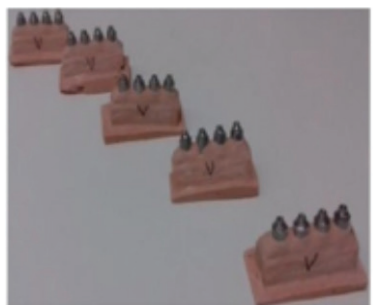

(b)
Figure 5 - a) Working casts obtained with open tray technique; b) Working casts obtained with closed tray technique. 


\subsection{Dimensional Analysis}

All samples and the master model received the master metallic structured fixed with threads Mix (Mult Unit M 1.4 x 3.5) under $20 \mathrm{Ncm}$ torque on each implant, calibrated with the aid of a torque wrench (Kit Protético, INP, SP, Brazil), following the manufacturer's instructions.

The marginal adaptation and the dimensional analysis of all groups were performed with the aid of a Stereoscopic Magnifying Glass (Physis; S/N: K300202053 3.0MP) with $x 60$ magnification, on three points on the labial surface of each implant, named implant A, B, C, and D.

The vertical misfit of each implant was calculated as the distance between the metallic structure and the analogue on each point. An arithmetic mean of each implant was obtained. Then, the median of each sample for each group was obtained with the mean of the four implants A, B, C, and D. Then, the mean values of the samples was the total mean of the group [Figure 6].

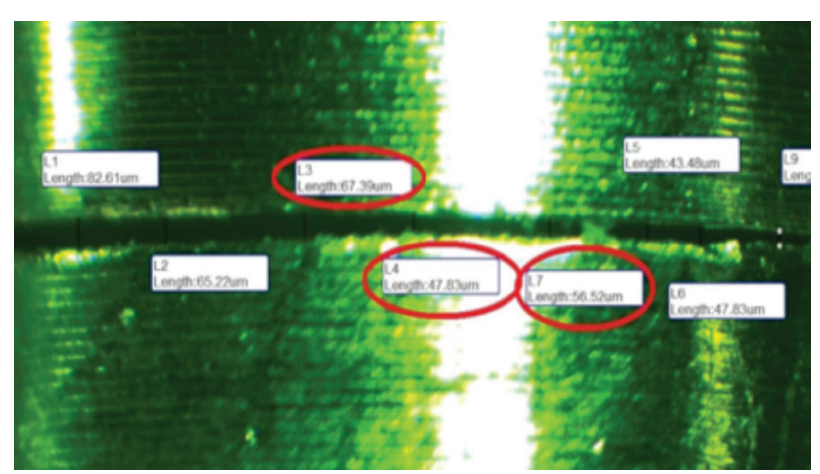

Figure 6 - Dimensional analysis (open tray, sample Aُ4, implant A3) of the magnified image obtained with the Stereoscopic Magnifying Glass on the three points at the center of the labial surface of the implant to measure the vertical misfit between the metallic structure and the analogue. The three measurements chosen are marked with red circle.

The means of group 1 (open tray) and 2 (closed tray) were compared to the control group (master model) and submitted to the statistical analysis with the aid of Bioestat 5.0 software.

\subsection{Statistical analysis}

Data was submitted to Dixon's normality test to verify extreme values. Due to unequal sample sizes, data normality and homogeneity was not confirmed and a non-parametric test was applied. Kruskal-Wallis test for independent samples was applied with level of significance of $(\mathrm{p}<0.05)$.

\section{RESULTS}

G1 (open tray) and G2 (closed tray) means and standard deviations were compared to the means of control group (master model) and described the vertical misfit between the metallic structure and the implants (Table I). The comparison between groups showed no statistically significant differences $(p=0.3465)$.

Table I - Mean and standard deviation of the studied groups

\begin{tabular}{|cc|}
\hline Group & Mean (SD) \\
\hline G1 & $24.6474 \pm 14.8883 \mu \mathrm{m}$ \\
\hline G2 & $26.2257 \pm 9.7421 \mu \mathrm{m}$ \\
\hline CG & $22.445 \pm 7.7106 \mu \mathrm{m}$ \\
\hline
\end{tabular}

G1- open tray (direct technique); G2-closed tray (indirect technique); CG- control group (master model).

\section{DISCUSSION}

Together with another factors, the accuracy of implant transfer impression technique plays a fundamental role in the passive adaptation of implant-supported prosthesis because the technique accounts for providing the working cast with the most reliable implant position similar to the position in the patient's mouth [1,4-5,7-9,11-15,19-24]. Passive adaptation is defined as the adequate positioning of all surfaces of both the implant and fixed (cemented or screwed) prosthesis, without application of forces. In these conditions, previous studies reported the vertical misfit between the metallic structure and the implants should respect the limits of distortion between $100-150 \mu \mathrm{m}$ to be considered as acceptable $[2,4-6,9,11-12,19,21]$. Values lower than 30 $\mu \mathrm{m}$ are not detectable to the naked eye [2]. Thus, according to the mean results obtained in the control group (22.445 $\mu \mathrm{m} \pm 7.7106)$, $\mathrm{G} 1(24.6474 \mu \mathrm{m} \pm 14.8883)$, and G2 (26.2257 $\mu \mathrm{m} \pm 9.7421)$, the adaptation of all studied 
samples was classified as acceptable because in most part of the analyses, the vertical misfit was not observed by naked eye.

The studies on the mechanical and/or biological complications due to poorly executed impressions that resulted on maladapted prostheses report consequences ranging from the possibility of implant component loss or fracture, porcelain fracture, structure fracture, occlusal alterations, pain, biofilm accumulation, peri-implant mucositis, which may evolve to peri-implantitis consequently leading to the loss of the osseointegration and implants. Thus, implant transfer impression techniques and innovative materials should aim at overcoming these problems clinically [2-5,7$8,14,17-22,26]$. Thus, the ideal implant transfer impression technique should provide greater comfort to the patient with greater practicality during the procedure, shorter working time, and lower cost. All these variables would influence on the accuracy and quality of the constructed transfer working casts $[9,12,23]$.

The literature lacks consensus on the best technique: some studies advocate the use of open tray (direct) technique [3,5,8,13,18,22,24,27] and other report no statistically significant differences between the techniques [19-20], which corroborates the results of this study (Kruskal-Wallis test; $\mathrm{p}=$ 0.3465). Further studies are necessary to complement these opinions expressed over the years.

The literature review of 59 studies published between 1990 and 2012 retrieved 56 in vitro studies and three case reports. Of these, 25 studies examined the open and closedtray implant transfer impression techniques. Twelve studies concluded that the open tray technique was the best and 11 studies found no statistically significant differences between the techniques. The authors concluded that the open tray techniques behave better, especially when more implants were involved [10].

A systematic review aimed to evaluate and compare the results obtained by 50 studies published between 1990 and 2013 on implant transfer impression techniques based on the respective techniques and methods used, advantages, and disadvantages. Of the 17 studies comparing the accuracy between the open and closed-tray techniques, 10 studies advocated the use of open tray technique and only one advocated the use of closed tray technique; eight studies reported no dimensional differences between the techniques [7].

A study surveyed 32 researches published between 2009 and 2013 to identify the most accurate implant transfer impression technique and the main factors accounting for affecting the accuracy and observed that in cases with four implants or more, six studies advocated the use of the open tray technique and four studies found similar results between the techniques. In the installation of three implants or lesser, two studies pointed out no differences between the techniques and two studies reported that the open tray technique had the greatest accuracy [17].

Both techniques have advantages, disadvantages, and clinical applications. The literature report that the open tray technique is more accurate than the closed tray technique and indicated for the impression of four implants or more. The rationale behind this indication is that the removal of the transfer copings together with the impression even considering the minimum movement of loosening avoids the implant angulation and internal movements in the impression material keeping the precision. The open tray technique drawbacks are longer working time and necessity of experience to construct the orifices in the trays with adequate location and diameter, which may interfere in the impression accuracy to numbers similar to that of closed tray technique $[2-5,12,18,20,22]$.

The closed tray technique has satisfactory results for the impression of up to three implants with a simpler and faster method. However, the disadvantages are the displacement of transfer copings and analogues in the impression material during the manual placement by the dentist, which distorts the impression and alters the accuracy of the transfer cast mainly in the case of multiple implants $[3,5,18,20,22]$.

The group 1 (open tray) showed the smaller distance (mean of $10.9567 \mu \mathrm{m}$ - sample \#1, implant \#4) and the greatest distance (mean of $63.77 \mu \mathrm{m}$ - sample \#3, implant \#3) between the master structure and implant. 
These data taken together with the mean of each group revealed greater variations in the results of group 1 (open tray). The median values for control group $(20.605 \mu \mathrm{m}), \mathrm{G} 1$ $(18.8833 \mu \mathrm{m})$, and $\mathrm{G} 2(23.635 \mu \mathrm{m})$ show the smallest values for the open tray technique.

This was an in vitro study, similar to most of the scientific literature researched. In vitro studies do not mimic the clinical conditions such as the interference of the texture of the teeth and gingiva, bite force, humidity, and temperature. Therefore, further in vivo studies are necessary to mimic the clinical situation through more accurate impressions demanding the dentist's expertise [3-4,8-10,14,16,20,22,25,27-28].

\section{CONCLUSION}

Both the open and closed-tray impression technique showed similar accuracy in the transfer of the implants. Considering the indications, contraindications, and clinical applications, the dentist should choose the most suitable technique for daily practice.

\section{REFERENCES}

1. Akalin ZF, Ozkan YK, Ekerim A. Effects of implant angulation, impression material, and variation in arch curvature width on implant transfer model accuracy.Int J Oral Maxillofac Implants. 2013 Jan-Feb;28(1):149-57.

2. Pujari M, Garg P,Prithviraj DR. Evaluation of accuracy of casts of multiple internal connection implant prosthesis obtained from different impression materials and techniques: an in vitro study. J Oral Implantol. 2014 Apr;40(2):137-45.

3. Patil R, Kadam P,Oswal C, Patil S, Jajoo S, Gachake A. A Comparative analysis of the accuracy of implant master casts fabricated from two different transfer impression techniques. J Int Soc Prev Community Dent. 2016 MarApr;6(2):142-8

4. Selvaraj S, Dorairaj J,Mohan J, Simon P.Comparison of implant cast accuracy of multiple implant impression technique with different splinting materials: an in vitro study. J Indian Prosthodont Soc. 2016 Apr-Jun;16(2):167-75.

5. Shankar YR, Sahoo S, Krishna MH, Kumar PS, Kumar TS, Narula S. Accuracy of implant impressions using various impression techniques and impression materials. J Dent Implant. 2016 Sep;6(1):29-36.

6. GuptaS, Narayan Al, Balakrishnan D. In Vitro comparative evaluation of different types of impression trays and impression materials on the accuracy of open tray implant impressions: a pilot study. Int J Dent. 2017 Epub;2017 Feb:6306530

7. Kim JH, Kim KR, Kim S. Critical appraisal of implant impression accuracies: a systematic review.J ProsthetDent. 2015 Aug;114(2):185-92.

8. Al Quran FA, Rashdan BA, AbuZomar AA, Weiner S. Passive fit and accuracy of three dental implant impression techniques. Quintessence Int. 2012 Feb;43(2):119-25.
9. de Avila ED, Barros LAB, Del'Acqua MA, Castanharo SM, Molo FdA. Comparison of the accuracy for three dental impression techniques and index: an in vitro study.JProsthodont Res. 20130ct:57(4):268-74.

10. Baig MR. Multi-Unit ImplantImpression Accuracy:A Review of The Literature. Quintessence Int. 2014 Jan;45(1):39-51.

11. Gibbs SB, Versluis A, Tantbirojn D, Ahuja S. Comparison of polymerization shrinkage of pattern resins. JProsthet Dent. 2014 Aug;112(2):293-8.

12. Marotti J, Tortamano P, Castilho TRRN, Steagall W, Wolfart S, Haselhuhn K. Accuracy of a self-perforating impression tray for dental implants. J Prosthet Dent. 20140ct;112(4):843-8.

13. Mostafa TMN, Elgendy MNM, Kashef NA, Halim MM. Evaluation of the precision of three implant transfer impression techniques using two elastomeric impression materials. Int J Prosthodont. 2010 NovDec;23(6):525-8.

14. Assunção WG, Britto RC, Ricardo Barão VA, Delben JA, dos Santos PH Evaluation of impression accuracy for implant at various angulations. Implant Dent. 2010 Apr;19(2):167-74.

15. Stimmelmayr M, ErdeltK, Güth JF, Happe A, Beuer F.Evaluation of impression accuracy for a four-implant mandibular model-a digital approach. Clin Oral Investig. 2012 Aug;16(4):1137-42.

16. Stimmelmayr M, Güth JF,ErdeltK, Happe A, Schlee M, Beuer F.Clinical study evaluating the discrepancy of two different impression techniques of four implants in an edentulous jaw. Clin Oral Investig. 2013 Nov;17(8):1929-35.

17. Moreira AHJ, Rodrigues NF, Pinho ACM, Fonseca JC, Vilaça JL. Accuracy comparison of implant impression techniques: a systematic review. Clin ImplantDentRelatRes. 2015 0ct;17 Suppl 2:e751-64.

18. Nakhaei M, Madani AS, Moraditalab A, Haghi HR. Three-Dimensional accuracy of different techniques for dental implants. Dent Res J (Isfahan).2015 SepOct;:12(5):431-7.

19. PeraF,PesceP,Bevilacqua M, SettiP,Menini M. Analysis of Different impression techniques and materials on multiple implants through 3-dimensional laser scanner. ImplantDent. 2016 Apr;25(2):232-7.

20. Haghi HR, Shiehzadeh M, Nakhaei M, Ahrary F,Sabzevari S. effect of technique and impression material on the vertical misfit of a screw-retained, three-unit implant bridge: an in vitro study. J Indian Prosthodont Soc. 2017 Jan-Mar;17(1):41-47.

21. de Faria JCB, Concílio LRS, Neves ACC, Miranda ME, Teixeira ML. Evaluation of the accuracy of different transfer impression techniques for multiple implants. Braz Oral Res. 2011Mar-Apr;25(2):163-7.

22. Kurtulmus-Yilmaz S, Ozan 0, Ozcelik TB, Yagiz A. Digital evaluation of the accuracy of impression techniques and materials in angulated implants. J Dent. 2014Dec;42(12):1551-9.

23. Dogan S, Schwedhelm ER, Heindl H,Mancl L, Raigrodski AJ. Clinical Efficacy of polyvinyl siloxane impression materials using the one-step two-viscosity impression technique.JProsthetDent.2015 Aug;:14(2):217-22.

24. BalaMurugan T,Manimaran P.Evaluation of accuracy of direct transfer snapon impression coping closed tray impression technique and direct transfer open tray impression technique: an in vitro study. J Indian Prosthodont Soc. 2013 Sep;13(3):226-232.

25. Santayana de Lima LM, Borges GA, Júnior LHB, Spohr AM. In vivo study of the accuracy of dual-arch impressions. J Int Oral Health. 2014 Jun;6(3):50-55.

26. Alikhasi M, Bassir SH, Naini RB. Effect of multiple use of impression copings on the accuracy of implant transfer. int joral maxillofac implants. 2013 MarApr;28(2):408-14. 
27. Tsagkalidis G, Tortopidis D, Mpikos P, Kaisarlis G, Koidis P. Accuracy of 3 different impression techniques for internal connection angulated implants. J Prosthet Dent.20150ct;114(4):517-23.
28. Stimmelmayr M, Beuer F,Edelhoff D, Güth JF.Implant impression techniques for the edentulous jaw: a summary of three studies. J Prosthodont. 2016 Feb;25(2):146-50.

\section{Karen Petená Moretti}

\section{(Corresponding address)}

Universidade Metodista de São Paulo - Faculdade de odontologia

São Paulo SP - Brasil

Endereço: Rua Giuliano Bugiardini, n 255 - Jardim Santa Emília

Date submitted: 2018 Mar 18

São Paulo - SP CEP: 04183-030 